\title{
ESTIMATION OF CORROSION RESISTANCE OF CURING MIXTURES BASED ON COAL-BEARING ROCKS FROM WESTERN DONBASS
}

\author{
V. Kovalenko ${ }^{1}$, V. Harkusha ${ }^{1 *}$ \\ ${ }^{l}$ Department of Construction, Geotechnics and Geomechanics, National Mining University, Dnipropetrovsk, Ukraine \\ *Corresponding author: e-mail vitaliagarkusha@yandex.ua, tel. +380997726878
}

\section{ОЦІНКА КОРОЗІЙНОЇ СТІЙКОСТІ ТВЕРДІЮЧИХ СУМІШЕЙ НА ОСНОВІ ВУГЛЕВМІЩУЮЧИХ ПОРІД ЗАХІДНОГО ДОНБАСУ}

\author{
В. Коваленко ${ }^{1}$, В. Гаркуша ${ }^{1 *}$ \\ ${ }^{l}$ Кафедра будівництва, геотехніки і геомеханіки, Національний гірничий університет, Дніпропетровськ, Украӥна \\ *Biдповідальний автор: e-mail vitaliagarkusha@yandex.иа, тел. +380997726878
}

\begin{abstract}
Purpose. Substantiation of possible use of coal-bearing rocks as a replacement for a part of the filler in the preparation of shotcrete for lining of mine workings in the conditions of mineralized mine water.

Methods. The research is based on carrying out corrosion testing of concrete specimens by dipping them into mine water. Chemical analysis of mine waters composition has been completed. A scanning microscope was used to study the state of concrete specimens microstructure.

Findings. A comparative analysis was conducted to evaluate of the cement rock resistance to mineralized water, depending on the composition of the starting components for the grouting and shotcrete mixtures is carried out. The change in the chemical composition of mine water after soaking concrete specimens in it is defined. Photographs of concrete specimens microstructure after soaking in ordinary and mineralized water for 6 and 8 months are shown.

Originality. Curing mixtures based on coal-bearing rocks from Western Donbass are mineralized water resistant and can act as a quality protection from aggressive water filtrationdue to the properties of rocks used as a filler.

Practical implications. The results can be used for the rational choice of the composition of the concrete mixture with the replacement of filler part with mine rock. That will enhance the long-term stability of the mine working lined by these compositions.
\end{abstract}

Keywords: concrete corrosion, durability, corrosion testing, mine rocks, mineralized water

\section{INTRODUCTION}

Using coal-bearing rocks as a replacement for a part of shotcrete filler applied to support permanent workings may affect on corrosion resistance of concrete. The degree of concrete corrosion in permanent underground workings depends on the aggressiveness of the environment, permeability of concrete and cement rock reactivity (Lagerblad, Fjällbergand, \& Vogt, 2010).

Knowing the degree of the environment aggressiveness and its influence on the formation of a particular type of concrete corrosion, it is necessary to choose a binding agent for curing mixture, the use of which in the underground bearing structures would increase the durability of concrete. The works of such prominent scientists: B.G. Skramtaev, A.E. Sheykin, S.A. Mironov, P.I. Bozhenov, A.E. Desov, N.A. Moshchanskiy, V.I. Soroker, S.V. Shestoperov etc., focus on improvement of concrete properties when it is used in complex hydraulic conditions. The works of N.G. Trupak, I.I. Vahramejev, S.D. Voronkevich, E.Ya. Kipco etc. are devoted to issues of developing theory and practice of rock grouting in mining.

The main factors that determine the resistance of concrete to aggressive fluids are: stability of the structureforming products of hydratation; density of cement rock and concrete; ability to partially or completely recover from damages due to further hydration of unreacted binder particles. One of the main theoretical assumptions of strength, corrosion resistance and durability of composite is to create the optimum microstructure of concrete stone, reducing porosity and improving crack resistance due to the directed use of mineral fillers. The most vulnerable point of composite materials is the contact zone "binder-filler". It is from this contact zone that the aggressive fluids begin to penetrate deep into the material and destroy it. 
Thanks to introduction of mineral admixtures, the filler smoothly penetrates into the cement matrix, and in this case the contact zone as such is absent. Formation of chemically resistant calcium silicate and zeolite in the contact zone leads to compaction of the concrete structure and reduction of its permeability. Physical and chemical processes of binding systems curing account for the formation of a strong conglomerate with complex chemical composition and capillary-porous structure of the cement rock that largely determines the intensity of corrosion processes between the external environment and the concrete (Dunne, Christodoulou, Newlands, McKenna, \& Goodier, 2015).

Since cement rock curing involves the natural process of its structure compaction, the filtration rate decreases. When the cement rock is exposed to seepage the second process takes place - dissolution of minerals hydration products and their removal from the rock. So, we observe two processes opposite in their character, thus the result will depend on which of these processes is dominant.

To reduce or eliminate concrete corrosion, it is necessary besides selecting an appropriate cement and filler to:

- bind partially or completely free calcium hydroxide $\mathrm{Ca}(\mathrm{OH})_{2}$ in the concrete into insoluble or poorly water soluble compounds;

- increase density and water resistance of concrete and mortars;

- introduce the admixtures reducing pore volume and, consequently, decreasing the expansion deformation, which increases concrete hydrophobization.

Contact of cement particles with water causes selective hydration of clinker minerals on the grain surface. First, tree-calcium aluminate $\mathrm{C}_{3} \mathrm{~A}$ and calcium alumoferrite $\mathrm{C}_{4} \mathrm{AF}$ are hydrated, then three-calcium silicate $\mathrm{C}_{3} \mathrm{~S}$ and only 1 hour later - two-calcium silicate $\mathrm{C}_{2} \mathrm{~S}$. After formation of the first layer of minerals, hydration of clinker minerals proceeds depending on their exposure - or rather, penetration of water into them. Cements which contain increased amounts of small and large crystals reach their absolute strength compared with cements containing crystals of homogeneous size. The process of cement hydration is superficial, so its mechanism does not depend on the large grains of cement, i.e. it is the same for cements with coarse and fine grinding (Van Heerden, 2004).

In 1952, V.M. Moskvin proposed the classification of the main types of concrete corrosion. During operation in adverse hydrogeochemical conditions, the following types of concrete corrosion may take place:
I type - leaching of calcium hydroxide $\mathrm{Ca}(\mathrm{OH})_{2}$. The components of cement rock are dissolved and removed from the concrete structure. This process can be particularly intense during water filtration through the thickness of the concrete lining;

II type - exchange reactions between the minerals of cement rock and magnesium salts of underground waters with the creation of products without binding properties;

III type-crystallization of salts in the concrete cracks, pores and capillaries, which causes a rise in internal stress and may eventually lead to the destruction of structural elements of concrete stone.

Rarely does only one type of corrosion occur, but one of them, as a rule, is dominant.

\section{MAIN PART}

For the research we used: cement of grade 500, natural quartz sand and rock from Heroiv Kosmosu mine at PJSC "DTEK Pavlohradvuhillia". The rocks, provided by mine for experiments, are a mixture of argillites and of aleurolites. In this paper, several recipes of grouting and shotcrete compositions were considered. Concrete samples were prepared to determine their properties.

Mine waters of Western Donbass are highly mineralized, corrosively active in relation to concretes and metal roof supports. They contain significant amounts of ion $\mathrm{Cl}^{-}$and $\mathrm{SO}^{--}$. Their total hardness ranges $10-25 \mathrm{mgEq} / \mathrm{L}, \mathrm{pH}=7-7.8$ (Kovalenko, 2012). Characteristics of underground waters of Western Donbass mines are presented in Table 1.

As mineralized mine water can affect the strength and durability of cement rock, the experimental studies were conducted to assess the impact of underground water on the quality of the coatings obtained by curing mixtures (Harkusha, 2015).

Comparative analysis of the compression strength was conducted for the samples that were curing in normal conditions and those that were curing in mineralized water for one year. Results of estimating cement rock resistance to mineralized water are shown in Table 2 .

From Table 2 it is obvious that during the period of 1 year mineralized mine water does not produce any adverse effect on the samples of solidifying mixtures the curing process continues. In this case, mineralized water is not an aggressive medium, because the samples continue to gain strength.

Table 1. Characteristics of underground waters of Western Donbass mines

\begin{tabular}{|c|c|c|c|c|c|c|c|c|}
\hline \multirow[t]{2}{*}{ Name of the mine } & \multirow[t]{2}{*}{$\mathrm{pH}$} & \multirow{2}{*}{$\begin{array}{c}\text { General } \\
\text { minera- } \\
\text { lization, } g / 1\end{array}$} & \multicolumn{4}{|c|}{$\begin{array}{l}\text { Chemical composition, } \\
\frac{\mathrm{mg} / \mathrm{dm}^{3}}{\% \mathrm{Eq}}\end{array}$} & \multirow{2}{*}{$\begin{array}{c}\text { Corrosion rate at } \\
K_{k}= \\
r \mathrm{Mg}^{++}-r \mathrm{HCO}_{3}>0, \\
\text { corrosive medium }\end{array}$} & \multirow{2}{*}{$\begin{array}{l}\text { Aggression } \\
\text { to metal } \\
\mathrm{SO}_{4}^{--}+\mathrm{Cl}^{-}\end{array}$} \\
\hline & & & $\mathrm{Cl}^{-}$ & $\mathrm{SO}_{4}^{--}$ & $\mathrm{Mg}^{++}$ & $\mathrm{HCO}_{3}^{-}$ & & \\
\hline Blahodatna & 7.0 & 23.3 & $\frac{14584}{99}$ & $\frac{6}{0.1}$ & $\frac{644}{12}$ & $\frac{85}{0.3}$ & 51.6 & $\begin{array}{c}\text { strongly } \\
\text { aggressive }\end{array}$ \\
\hline Zakhidno-Donbaska & $6.5-7.0$ & 36.5 & $\frac{23049}{98.6}$ & $\frac{320}{1}$ & $\frac{2152}{27}$ & $\frac{140}{0.3}$ & 174.3 & $\begin{array}{l}\text { strongly } \\
\text { aggressive }\end{array}$ \\
\hline Heroiv Kosmosu & 6.9 & 27.2 & $\frac{17375}{99}$ & $\frac{201}{0.1}$ & $\frac{1520}{25}$ & $\frac{1280}{0.4}$ & 122.9 & $\begin{array}{l}\text { strongly } \\
\text { aggressive }\end{array}$ \\
\hline Stashkova & 7.4 & 3.9 & $\frac{1687}{71}$ & $\frac{687}{14}$ & $\frac{328}{22}$ & $\frac{329}{5.4}$ & 16.6 & $\begin{array}{l}\text { strongly } \\
\text { aggressive }\end{array}$ \\
\hline
\end{tabular}


Table 2. Results of estimating cement rock resistance to mineralized water

\begin{tabular}{|c|c|c|}
\hline \multirow[t]{2}{*}{ Composition } & \multicolumn{2}{|c|}{ Compressive strength } \\
\hline & $\begin{array}{l}\text { at the age of } 28 \text { days, } \\
\qquad \mathrm{MPa}\end{array}$ & $\begin{array}{l}\text { after } 12 \text { months'soaking } \\
\text { in mine water, } \mathrm{MPa}\end{array}$ \\
\hline \multicolumn{3}{|c|}{ Grouting mixture } \\
\hline Cement : Sand : Rock $=1: 1: 2$ & 11.37 & 12.9 \\
\hline Cement : Sand : Rock $=1: 2: 1$ & 18.78 & 23.9 \\
\hline Cement : Sand : Rock $=1: 3: 0$ & 16.74 & 22.8 \\
\hline \multicolumn{3}{|c|}{ Shotcrete and shotcreting mixtures } \\
\hline Cement : Sand : Rock $=1: 1: 2$ & 19.87 & 20.0 \\
\hline $\begin{array}{l}\text { Cement : Sand : Rock }=1: 1: 2+3 \% \text { silica gel }+ \\
+3 \% \text { hydrophobizator }\end{array}$ & 17.80 & 25.1 \\
\hline Cement : Sand : Rock $=1: 1: 2+3 \%$ silica gel & 15.20 & 22.3 \\
\hline $\begin{array}{l}\text { Cement : Sand : Rock }=1: 1: 2+20 \% \text { polyvinyl } \\
\text { acetate emulsion }\end{array}$ & 15.90 & 24.0 \\
\hline
\end{tabular}

Analysis of the results indicates that after curing in mineralized water the strength of the concrete samples increased by $10-30 \%$ in comparison with strength of the samples curing in normal conditions. Aggressive influence can become evident in later periods of concrete samples' staying in contact with mineralized water (Kurilko, Drozdov, Alekseev, \& Nikiforova, 2014).

Table 3 shows changes in the chemical composition of mine water after one-year immersion of the curing mixtures samples based on mine rocks. In the investigated solution, the content of almost all chemical elements has increased. It is especially necessary to note the increase in calcium content in the mine water from 1.9 to $4.8 \mathrm{~g} / \mathrm{dm}^{3}$ which testifies to corrosion of I and II type between water environment and the immersed concrete sample. For the case of type III corrosion, as salts accumulate in the pores of the concrete at the initial stages, it gets compacted.

Table 3. Changes in the chemical composition of mine water

\begin{tabular}{lcccc}
\hline \multirow{2}{*}{ Defined characteristics } & Measure & \multicolumn{2}{c}{ Water composition } & Increase / \\
\cline { 3 - 4 } & unit & initial & after samples' soaking & decrease, \% \\
\hline Hydrogen index $(\mathrm{pH})$ & unit & 6.60 & 6.60 & 0.00 \\
Total hardness & $\mathrm{mgEq} / \mathrm{dm}^{3}$ & 161.43 & 416.51 & 258.00 \\
Chlorides & $\mathrm{mg} / \mathrm{dm}^{3}$ & 19285.00 & 53344.00 & 276.60 \\
Sulfates & $\mathrm{mg} / \mathrm{dm}^{3}$ & 74.00 & 606.00 & 818.90 \\
Nitrates & $\mathrm{mg} / \mathrm{dm}^{3}$ & 10.00 & - & - \\
Potassium + sodium & $\mathrm{mg} / \mathrm{dm}^{3}$ & 8867.00 & 25365.00 & 286.00 \\
Calcium & $\mathrm{mg} / \mathrm{dm}^{3}$ & 1905.00 & 4841.00 & 254.10 \\
Magnesium & $\mathrm{mg} / \mathrm{dm}^{3}$ & 807.00 & 2115.00 & 262.10 \\
\hline
\end{tabular}

If this process is developing slowly, filling of the pores and hollows in the concrete by crystalline formations and resulting concrete compaction create an illusion that everything goes the right way. For a certain period of time, the concrete strength increases and exceeds the strength of the concrete that was not subjected to the action of aggressive environment. Hence sometimes it is not possible to recognize initial forms of type III corrosion developing. Only after the appearance of significant tensile forces in the pores' and capillaries' walls, caused by the continuing growth of crystals, the structural elements of the cement rock are destroyed and therefore its strength decreases noticeably.

Therefore, when evaluating conditions for potential type III corrosion, one should use the results of shortterm tests cautiously if the cement durability criterion is compressive strength. On the samples curing in mine water, whitish scurf and salt crystals were formed. This suggests that there is a type III corrosion process, namely, the crystallization of salts in the cracks, pores and capillaries of the cement rock. The salt accumulation increases the internal stress and may eventually result in destruction of the structural elements of the cement rock.

Corrosion effect is greatly enhanced at alternate immersion of concrete into the salt solution and drying out.
This also happens during partial immersion since the chemical processes of interaction between aggressive environment and cement rock are accompanied by the physical processes of corrosion products or soluble components crystallization. Besides, the processes of mass transfer are enhanced, for example, as a result of capillary forces.

Figures 1, 2, 3 and 4 present micrographs of the samples that were in contact with mineralized water, and the samples that did not have contact with mineralized water.

Most easily soluble product of cement hydration is calcium hydroxide whose leaching results in hydrolysis of the cement clinker. What happens first is the destruction of polybasic compounds such as tricalcium and dicalcium hydrosilicates, followed by low-basic compounds. Tetracalcium alumina ferrite $4 \cdot \mathrm{CaO} \cdot \mathrm{Al}_{2} \mathrm{O}_{3} \cdot \mathrm{FeO}$ are the least resistant of hydroaluminates.

I type concrete corrosion resistance depends on the chemical composition of the cement used. Prevalence of highly basic compounds in the cement (alite $\mathrm{C}_{3} \mathrm{~S}$, belite $\mathrm{C}_{2} \mathrm{~S}$ ) reduces cement resistance if their destruction is due to the dissolution of its component parts, i.e. the solution acquires a large amount of $\mathrm{CaO}$.

Sulfates of sodium and potassium present in water, which are in contact with the cement matrix, can improve 
the solubility of the cement rock components and thereby accelerate the development of I type corrosion, on the other hand, they can cause the development of metabolic reactions of $\mathrm{Ca}^{2+}$ cation substitution from the cement matrix, i.e. cause type II corrosion.

The corrosion rate develops rapidly in the initial period and gradually fades with time. The change in corrosion rate is related to formation on the reaction surface of corrosion products which inhibit the access of aggressive substances to it.

Initially, the corrosion rate is determined by the rate of aggressive environment interaction with the concrete components or dissolution rate. However, quite soon reaction products appear on the surface, and corrosion rate becomes affected by the diffusion of aggressive fluids onto the reaction surface. (a)

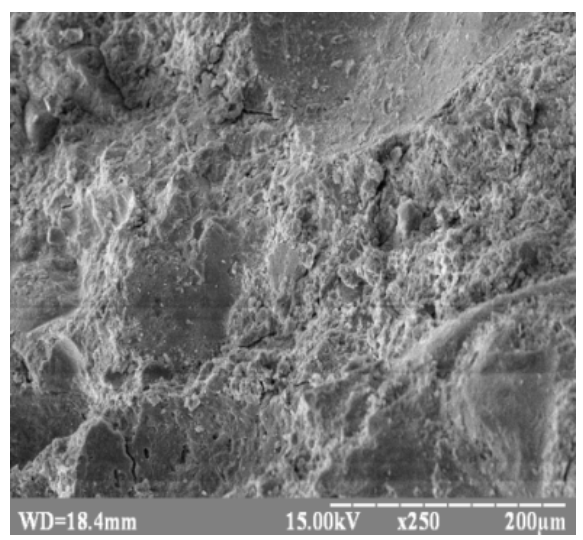

(b)

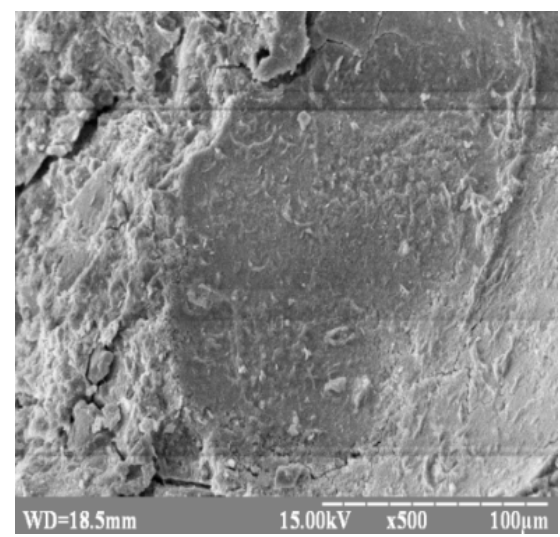

Figure 1. Micrographs of cement rock based on mine rocks that was curing in normal conditions

(a)

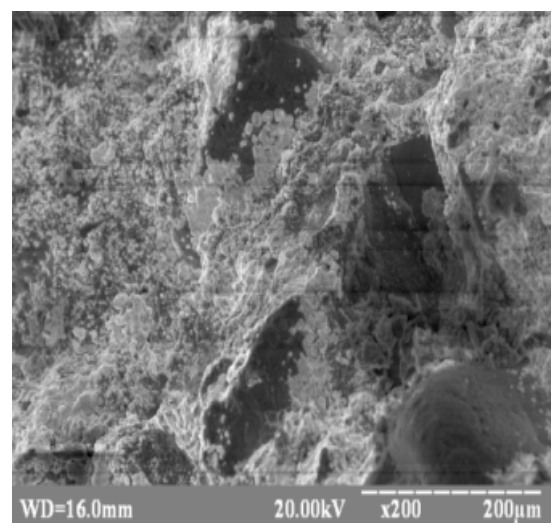

(b)

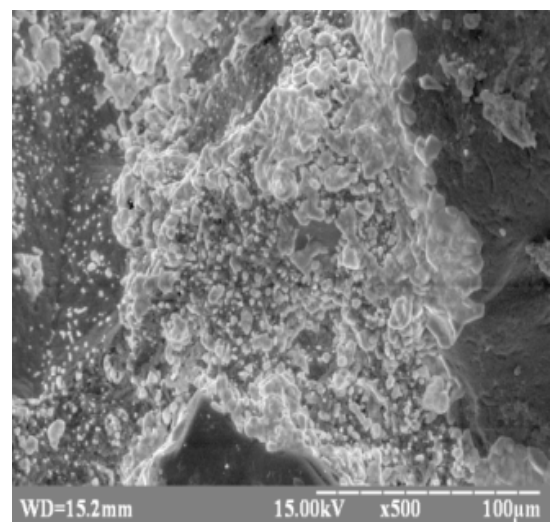

(c)

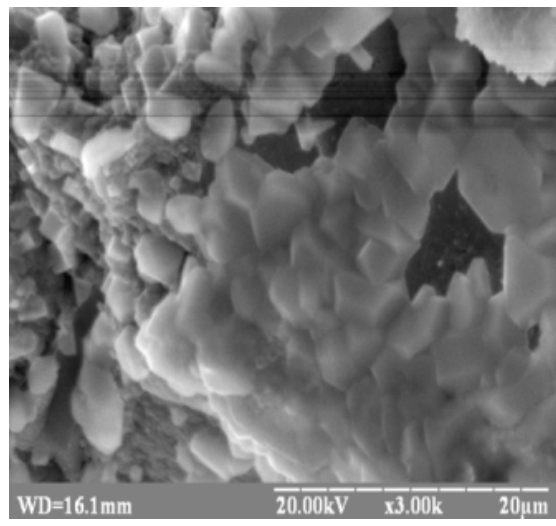

Figure 2. Micrographs of cement rock based on mine rocks that was in contact with mineralized mine water for 6 months

(a)

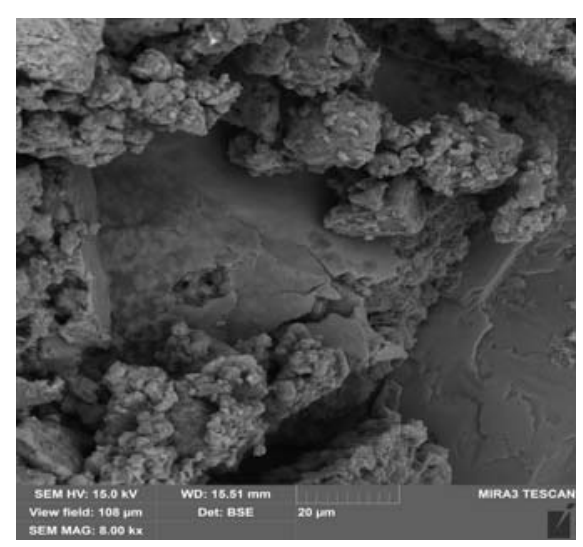

(b)

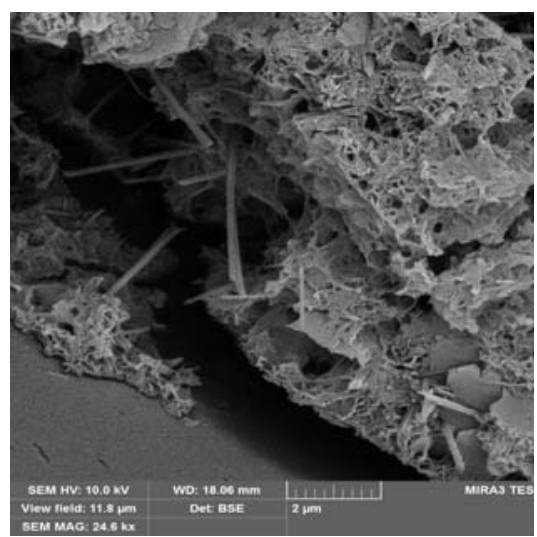

(c)

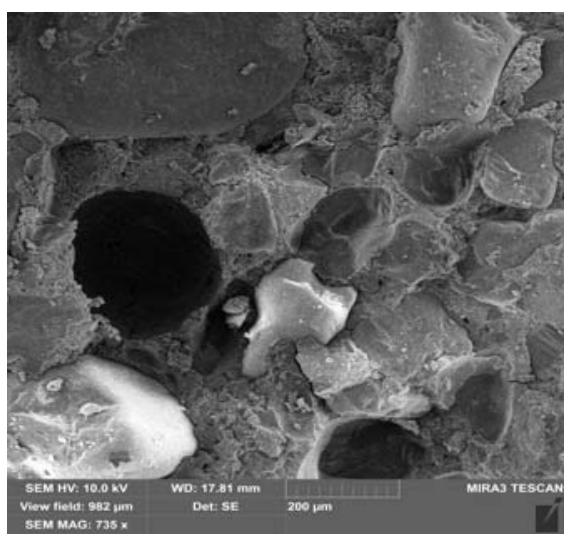

Figure 3. Micrographs of cement rock based on mine rocks that stayed in contact with mineralized mine water for 8 months (the sample selected directly on the cube surface) 
(a)

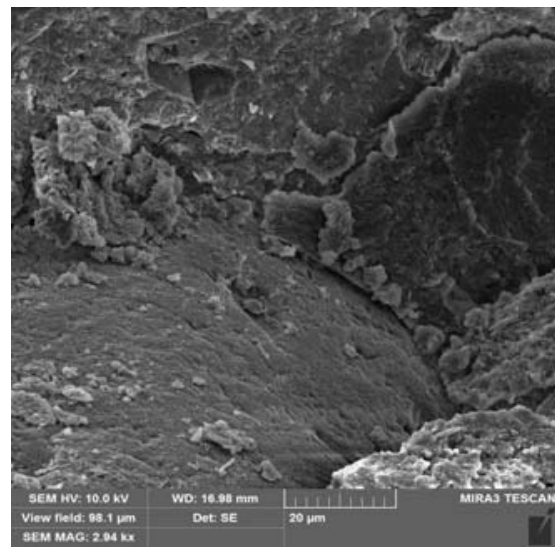

(b)

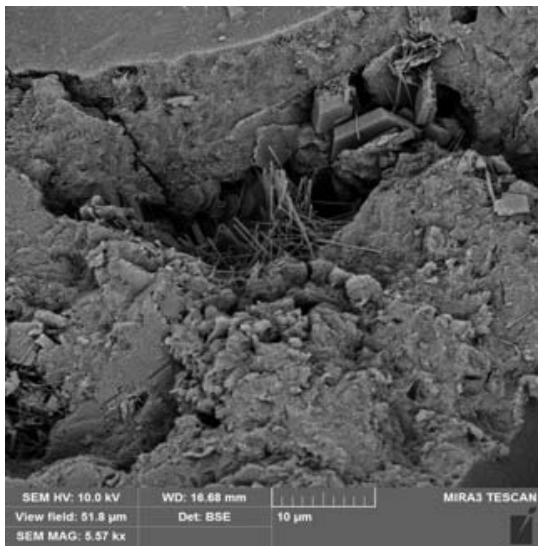

(c)

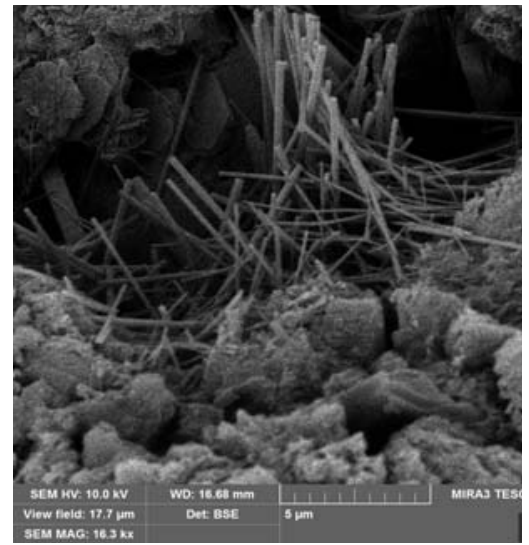

Figure 4. Micrographs of cement rock based on mine rocks that stayed for 8 months in contact with mineralized mine water (the sample selected at a depth of $4 \mathrm{~cm}$ from the cube surface)

During this time, the so-called diffusion-kinetic period, the corrosion rate is defined both by the rate of chemical interaction and the diffusion of the reactants.

In the underground structures corrosion products tend to remain in the place of their formation. Thus there is a gradual increase in the thickness of the corrosion product layer and increase in its density. In these conditions, the corrosion rate and the depth of concrete deterioration is determined by diffusion of reactants and the degree of aggressiveness.

Currently there are no developed techniques yet, which would allow to determine reliably the depth of concrete destruction under corrosion, on the basis of data about its composition and conditions of aggressive action. Existing methods for predicting the depth of concrete corrosion are based on preliminary tests that help to define the concrete corrosion depth during the set time period under the long-term impact taking into account the laws of corrosion development.

\section{CONCLUSIONS}

Concrete corrosion processes in conditions of Western Donbas mines are not so intense that the concrete coating becomes defective before the lifetime expiration term of most permanent workings, where we plan to use the developed mixture compositions. Thus, the proposed compositions of curing mixtures based on coal-bearing rocks from mines of Western Donbass are resistant to the effects of mineralized mine water. Moreover, they can be an effective protective coating for metal components of mining roof support, and act as a grout curtain.

The introduction of corrective admixtures in the obtained curing mixtures is possible only if it is technologically and economically reasonable. The conducted studies indicate that such set of activities often does not produce a significant effect.

The obtained compositions of curing mixtures are resistant to the impact of mineralized mine water. Moreover, they can be a high quality sealing curtain, because the filler used (a mixture of argillites and of aleurolites) can absorb and retain water.

\section{ACKNOWLEDGEMENT}

The authors express their gratitude to the administration of the Department of Construction, Geotechnics and Geomechanics of the National Mining University (Dnipropetrovsk, Ukraine), represented by O. Shashenko and A. Solodiankin, as well as to all those who helped in carrying out works related to preparation of this paper.

\section{REFERENCES}

Dunne, D., Christodoulou, C., Newlands M.D., McKenna, P., \& Goodier, C.I. (2015). Chloride Ingress Testing of Concrete. In International Conference on Concrete Repair, Rehabilitation and Retrofitting (pp. 3-9). Germany: Leipzig. http://dx.doi.org/10.1201/b18972-3

Harkusha, V. (2015). Waste Rock Sprayed Concrete Mixtures for Coal Mines Workings Support. Naukovyi Visnyk Natsionalnoho Hirnychoho Universytetu, (3), 17-23.

Kovalenko, V. (2012). Zashchita metallicheskoy krepi ot korrozii $s$ ispol'zovaniyem torkret-betona. Dnipropetrovsk: Natsionalnyi Hirnychyi Universytet.

Kurilko, A.S., Drozdov, A.V., Alekseev, K.N., \& Nikiforova, A.D. (2014). Vliyanie khloridnykh kal'tsievykh rassolov na prochnost' torkret-betona, izgotovlennogo na osnove mestnykh zapolniteley (na primere rudika "Udachnyy"). Gornyy informatsionno-analiticheskiy byulleten', (2), 17-21.

Lagerblad, B., Fjällbergand, L., \& Vogt, C. (2010). Shrinkage and Durability of Shotcrete. Shotcrete: Elements of a System, 173-180.

http://dx.doi.org/10.1201/b10545-21

Van Heerden, D. (2004). The Use of Calcium Aluminate Cement in Shotcrete. In Shotcrete: More Engineering Developments: Proceedings of the Second International Conference on Engineering Developments in Shotcrete (pp. 267-274). Australia: Cairns, Queensland. http://dx.doi.org/10.1201/9780203023389.ch30 


\section{ABSTRACT (IN UKRAINIAN)}

Мета. Обгрунтування можливості використання вуглевміщуючих порід у якості заміни частини заповнювача в процесі приготування бетону для кріплення гірничих виробок в умовах мінералізованих шахтних вод.

Методика. Робота базується на проведенні корозійних випробувань бетонних зразків шляхом занурення їх у шахтну воду. Виконано хімічний аналіз складу шахтних вод. Використаний растровий мікроскоп для дослідження стану мікроструктури бетонних зразків.

Результати. Виконано порівняльний аналіз оцінки стійкості цементного каменю до впливу мінералізованої води залежно від складу вихідних компонентів для тампонажних, торкрет-бетонних і набризкбетонних сумішей. Визначено зміну хімічного складу шахтної води після витримки у ній бетонних зразків. Наведено фотографії мікроструктури бетонних зразків після витримки у нормальних умовах та мінералізованої води протягом 6 і 8 місяців.

Наукова новизна. Твердіючі суміші на основі вуглевміщуючих порід Західного Донбасу достатньо стійкі до впливу мінералізованих вод та є якісною протифільтраційною завісою завдяки властивостям порід, використаних у якості заповнювача.

Практична значимість. Отримані результати можуть бути використані для раціонального підбору складу бетонної суміші із заміною частини заповнювача шахтної породою, що дозволить підвищити тривалу стійкість гірничої виробки, закріпленої з використанням даних складів.

Ключові слова: корозія бетону, міцність, корозійні випробування, шахтні породи, мінералізовані води

\section{ABSTRACT (IN RUSSIAN)}

Цель. Обоснование возможности использование углевмещающих пород в качестве замены части заполнителя в процессе приготовления бетона для крепления горных выработок в условиях минерализованных шахтных вод.

Методика. Работа базируется на проведении коррозионных испытаний бетонных образцов путем погружения их в шахтную воду. Выполнен химический анализ состава шахтных вод. Использован растровый микроскоп для исследования состояния микроструктуры бетонных образцов.

Результаты. Выполнен сравнительный анализ оценки устойчивости цементного камня к воздействию минерализованной воды в зависимости от состава исходных компонентов для тампонажных, торкрет-бетонных и набрызгбетонных смесей. Определено изменение химического состава шахтной воды после выдержки в ней бетонных образцов. Представлены фотографии микроструктуры бетонных образцов после выдержки в нормальных условиях и минерализованной воде в течение 6 и 8 месяцев.

Научная новизна. Твердеющие смеси на основе углевмещающих пород Западного Донбасса устойчивы к влиянию минерализованных вод и являются качественной противофильтрационной завесой благодаря свойствам пород, использованных в качестве заполнителя.

Практическая значимость. Полученные результаты могут быть использованы для рационального подбора состава бетонной смеси с заменой части заполнителя шахтной породой, что позволит повысить длительную устойчивость горной выработки, закрепленной с использованием данных составов.

Ключевые слова: коррозия бетона, прочность, коррозионные испытания, шахтные породы, минерализованные воды

\section{ARTICLE INFO}

Received: 24 June 2016

Accepted: 19 July 2016

Available online: 30 September 2016

\section{ABOUT AUTHORS}

Vladyslav Kovalenko, Candidate of Technical Sciences, Associate Professor of the Department of Construction, Geotechnics and Geomechanics, National Mining University, 19 Yavornytskoho Ave., 4/40, 49005, Dnipropetrovsk, Ukraine. E-mail: kovalenko_vlad@mail.ru

Vitaliia Harkusha, Postgraduate Student of the Department of Construction, Geotechnics and Geomechanics, National Mining University, 19 Yavornytskoho Ave., 4/15, 49005, Dnipropetrovsk, Ukraine. E-mail: vitaliagarkusha@yandex.ua 